\title{
Member Spotlights
}

James L. Gibson, Sidney W. Souers Professor of Government at Washington University in St. Louis, Professor Extraordinary in Political Science and a fellow at the Centre for Comparative and International Politics, Stellenbosch University (South Africa), was recently elected as an Honorary Foreign Associate of the Academy of Science of South Africa (ASSAf). Professor Gibson is the author of the so-called "Overcoming Trilogy" (Overcoming Intolerance, Overcoming Apartheid, and Overcoming Historical Injustices), a series of three books about South Africa's transition from apartheid.

Pearl K. Dowe, Asa Griggs Candler Professor of Political Science and African American Studies at Emory University, won the Anna Julia Cooper Outstanding Publication Award from the Association for the Study of Black Women in Politics. The award recognized her article "Resisting Marginalization: Black Women's Political Ambition and Agency" in PS: Political Science \& Politics.

Thea Riofrancos, formerly assistant professor of political science at Providence College, is now associate professor.
Kelebogile Zvobgo, formerly a PhD candidate in political science and international relations at the University of Southern California, will begin as assistant professor of government at The College of William \& Mary in fall 2021.

Christian Dyogi Phillips, assistant professor of political science at the University of Southern California, received a Russell Sage Foundation pipeline grant for her project "Essential Labor: Asian American Women Workers and the Intersectional Politics of Incorporation."

Tye Rush, a PhD candidate in political science at the University of California, Los Angeles, was awarded a Ford Foundation dissertation fellowship.

\section{KEEP US INFORMED}

Contact publications@apsanet.org to submit a member spotlight to Political Science Today.

\section{Northeastern Professor Costas Panagopoulos Co-chairs Massachusetts Commission Charged with Recommending Campaign Finance Amendments to the US Constitution}

n November 2018, Massachusetts voters approved Ballot Question 2, to create the Citizens Commission Concerning a Constitutional Amendment for Government of the People. The Commission's mission is to provide recommendations about how Massachusetts can support amending the US Constitution to regulate election spending and to affirm that corporations do not possess inalienable rights enshrined in it.

Costas Panagopoulos, professor of political science and chair of the Department of Political Science at Northeastern University, was appointed by Massachusetts State Senate President Karen Spilka to serve on the 15 member commission, which later elected him to co-chair the group.

Since the US Supreme Court's ruling in Citizens United (2010), corporations and outside groups have been free to spend an unlimited amount of money independently on elections. According to the Center for Responsive Politics, outside groups have poured $\$ 4.5$ billion into elections in the last decade, $\$ 1$ billion of which was provided by just 10 donors.

The influence of corporate money on American democracy has caused citizens to feel increasingly feel powerless in the face of growing corporate influence, a trend Panagopoulos does not believe is sustainable. "Democracy cannot persist-let alone flourish-when average citizens feel as disenfranchised and disempowered as they do today," he said.

Panagopoulos and the Citizens Commission view Constitu-

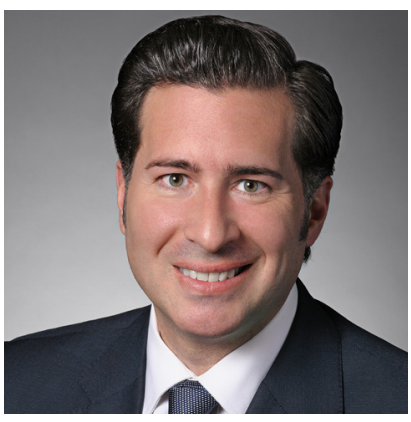

tional amendment as the best way to restore fairness to the electoral process. "It may be our last best hope to restore sensible campaign finance regulation and to rescue American democracy from the corporate stranglehold currently choking it," said Panagopoulos in a speech at the Massachusetts State House in January 2020.

The Commission released two reports based on extensive research and testimony at 20 public hearings. The first report, released in January 2020, summarized the impact of corporate and outside group election spending on recent elections in Massachusetts and across the country. In the second report, released on September 17, 2020-Constitution Day-the Citizens Commission recommended language for two, separate amendments to regulate campaign spending and to affirm that artificial entities, such as corporations, do not possess inalienable rights.

The Citizens Commission argues that amending the Constitution to address campaign finance would help to restore public confidence in American elections and democracy. The battle now moves to a national stage, where 38 states would need to ratify a constitutional amendment. 